\title{
Octafluoropropane Concentration Dynamics On Board the International Space Station
}

\author{
J. L. Perry \\ National Aeronautics and Space Administration
}

Copyright $\odot 2003$ SAE International

\begin{abstract}
Since activating the International Space Station's (ISS) Service Module in November 2000 , archival air quality samples have shown highly variable concentrations of octafluoropropane in the cabin. This variability has been directly linked to leakage from air conditioning systems on board the Service Module, Zvezda. While octafluoropropane is not highly toxic, it presents a significant challenge to the trace contaminant control systems. A discussion of octafluoropropane concentration dynamics is presented and the ability of on board trace contaminant control systems to effectively remove octafluoropropane from the cabin atmosphere is assessed. Consideration is given to operational and logistics issues that may arise from octafluoropropane and other halocarbon challenges to the contamination control systems as well as the potential for effecting cabin air quality.
\end{abstract}

\section{INTRODUCTION}

Archival air quality samples have shown significant octafluoropropane (Freon 218) concentration variation in the cabin since activating the International Space Station's (ISS) Service Module in November 2000. As shown by Figure 1, Freon 218 was undetectable before the Service Module's activation in November 2000. After that, Freon 218 was detected in the cabin but at concentrations usually below $10 \mathrm{mg} / \mathrm{m}^{3}$. Between late March and early April 2001 , a step increase to just over $20 \mathrm{mg} / \mathrm{m}^{3}$ occurred. The concentration continued to increase slowly to more than $75 \mathrm{mg} / \mathrm{m}^{3}$ in August. Russian experts reported that between June 26 and August 16, approximately 200 grams of Freon 218 leaked from one of the redundant air conditioning systems at a rate of $4 \mathrm{~g} / \mathrm{day}$. Each air conditioning unit contains approximately 750 grams of Freon 218. This confirmed leak accounts for the noted increase in cabin concentration during that time. Between August 16 and 27, the leak rate increased to approximately $20 \mathrm{~g} /$ day. From late June through late August, a total of $400 \mathrm{~g}$ of Freon 218 leaked into the cabin. During repairs, it was estimated that an additional $130 \mathrm{~g}$ was released. In total, nearly all of the 750 grams released. In total, nearly all of the 750 grams of Freon 218 leaked into the cabin. This large leak accounts for the peak concentrations that exceeded $600 \mathrm{mg} / \mathrm{m}^{3}$. Fortunately, this concentration did not exceed the NASA Spacecraft Maximum Allowable Concentration (SMAC) of $85,000 \mathrm{mg} / \mathrm{m}^{3}$.

During the period between September and December 2001 , cabin air quality samples returned from the ISS indicated a sustained octafluoropropane concentration in excess of $250 \mathrm{mg} / \mathrm{m}^{3}$ in the cabin. This was indicative of a steady 2-g/day leak of Freon 218. In December 2001, a second confirmed leak from the second air conditioning unit was reported. This unit was shut down but continued to leak until approximately January 1, 2002 by which time nearly all the Freon 218 had leaked into the cabin. Repairs to the air conditioning systems were successful and the on-board contamination control systems reduced the concentration below $20 \mathrm{mg} / \mathrm{m}^{3}$ by late May 2002.

\section{AN AIR QUALITY CONTROL CHALLENGE}

The cabin air quality control equipment on board the ISS consists of two primary units.[1,2,3] One is housed in the Russian Segment's service module, Zvezda. Called

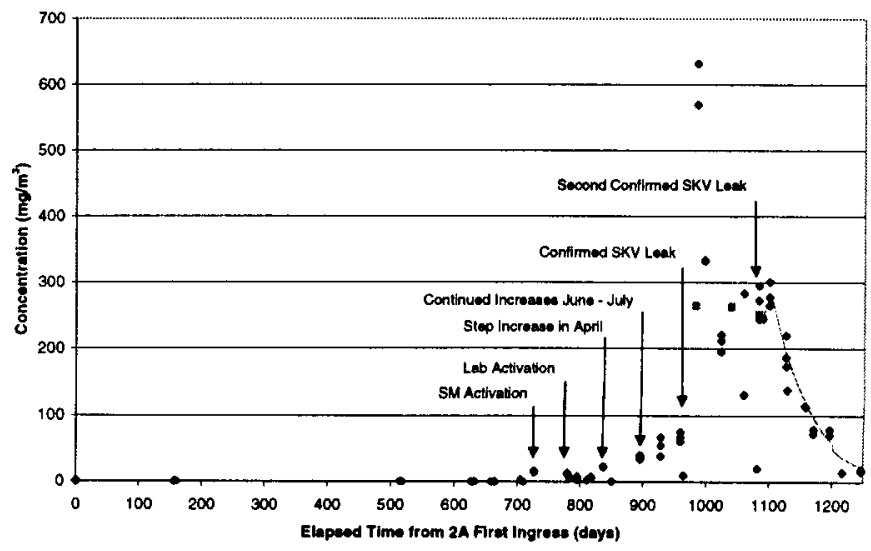

Figure 1. Freon 218 in the ISS Cabin - December 1998 to May 2002 
the micro-purification unit, it is known by its Russian acronym, BMP. The BMP removes volatile organic compounds (VOCs) from the cabin air by using adsorption and ambient temperature catalytic oxidation. Components include one expendable and 2 regenerable activated carbon beds plus a bed of ambient temperature catalyst. The carbon beds remove VOCs while the catalyst bed converts carbon monoxide to carbon dioxide. The second air quality control unit, the trace contaminant control subassembly (TCCS), is housed in the U.S. Segment's laboratory module, Destiny. The TCCS provides the same function as the BMP but accomplishes that function using adsorption and thermal catalytic oxidation. Primary components include an expendable activated charcoal bed assembly (CBA), a thermal catalytic oxidizer assembly (COA), and a sorbent bed assembly (SBA). The CBA removes VOCs and ammonia while the COA converts light VOCs, methane, and carbon monoxide to carbon dioxide. The SBA removes any acid gases from the process air stream that may be produced if halocarbons enter the COA.

\section{OPERATIONS FOR FREON 218 CONTROL}

To remove the Freon 218 released into the cabin during the two air conditioner failures, the BMP was operated in a rapid regeneration mode. In this mode, the activated charcoal beds are regenerated at 2-day intervals rather than the normal 20-day interval. The TCCS was shut down because of concern that Freon 218 could be oxidized to hydrogen fluoride (HF) in the TCCS's catalytic oxidizer. The concern surrounding TCCS operation was primarily excessively rapid consumption of the granular lithium hydroxide ( $\mathrm{LiOH}$ ) contained in its SBA that scrubs the exhaust gases from the COA. At prevailing concentrations and using bromotrifluoromethane (Halon 1301), that oxidizes at $10 \%$ efficiency, as a model for Freon 218 oxidation, it was estimated that up to $12 \%$ of the SBA's capacity may have been consumed between early April and late August 2001.[4] The TCCS remained shut down until late September when it was projected that Freon 218 concentrations would be significantly lower.

However, data reported from air quality samples collected between September and December 2001 indicated that the Freon 218 concentration remained higher than $200 \mathrm{mg} / \mathrm{m}^{3}$. With the TCCS operating and using the assumption of $10 \%$ oxidation efficiency based upon the Halon 1301 model, the SBA's capacity would be nearly depleted. To complicate matters, Zvezda's second air conditioning unit began to leak. That leak was confirmed in early December. Again, the TCCS was shut down and the BMP was configured to operate in a rapid regeneration mode. Because the concentrations reported from samples collected at the end of the docked phase of STS-108/UF-1 remained high, the TCCS was not restarted. The TCCS was not restarted until testing could be conducted on the ground to better understand the effects that Freon 218 in the cabin may have on its performance and logistics management.
FREON 218 OXIDATION IN THE TCCS

Because there were no data readily available on Freon 218 oxidation in the TCCS's thermal catalytic oxidizer, conservative assumptions had to be made to avoid hardware damage and potential risks to crew health. Central to TCCS operations management under the circumstances of a Freon 218 leak during the period between September 2001 and February 2002 is the assumption that it behaves similarly to Halon 1301 in the COA. Experiments with Halon 1301 documented by Reference 4 found that $10 \%$ of the amount entering the COA is oxidized with significant production of $\mathrm{HF}$ as a reaction product. Using Halon 1301's behavior as the model for Freon 218 oxidation is considered conservative because the literature indicates that long chain, unbranched fluorocarbons typically do not oxidize at temperatures below $600^{\circ} \mathrm{C}\left(1,112^{\circ} \mathrm{F}\right)$.[5] The TCCS's COA operates at $400^{\circ} \mathrm{C}\left(750^{\circ} \mathrm{F}\right)$. However, because a catalyst is involved, it was considered that a small amount of the entering Freon 218 could be oxidized. In general, the amount was thought to be much less than $10 \%$ and most likely less than $1 \%$. Because no definitive literature data were found on Freon 218 oxidation at the conditions that exist in the COA and the assumption that Freon 218 behaved similarly to Halon 1301 negatively affected TCCS operational flexibility, a test was developed to fill the information void.

\section{TEST OVERVIEW}

A simple test was designed to determine to what degree Freon 218 oxidizes in the TCCS's COA. Specific objectives of the test were the following:

1. Determine the extent of Freon $\mathbf{2 1 8}$ oxidation in the TCCS COA.

2. Determine the stability of Freon $\mathbf{2 1 8}$ oxidation if it is found to oxidize.

3. Determine the SBA service life based on test results and in-flight air quality data.

In the test, pure Freon 218 was pumped into the process air stream of a flight-like TCCS COA unit to produce a predetermined inlet concentration. The process air exiting the COA was sampled and tested for HF content.

The TCCS COA unit used for testing is a prototype built by Lockheed Missiles and Space Co., Inc. in Sunnyvale, California in 1974.[6] The unit has a flight-like process air flow path, operates at the same temperature, employs the same heating concept, and is packed with Engelhard Corp. $0.5 \% \mathrm{Pd}$ on alumina catalyst pellets. The primary difference that has bearing on performance of the COA used for testing and the flight unit is the annular catalyst bed size. The unit used for testing has a larger catalyst bed that has a $12.8-\mathrm{cm}$ outside diameter, $6.8-\mathrm{cm}$ inside diameter, and 9.5 -cm length $(5$-inch $O D \times 2.7$-inch ID $\times$ 3.7-inch length) that provides a residence time of 0.69 seconds. This is $68 \%$ longer than the 0.41 -second residence time provided by the flight design that has a 12.5- 
$\therefore \quad \mathrm{cm}$ outside diameter, $7-\mathrm{cm}$ inside diameter, and $6.1-\mathrm{cm}$ length (4.9-inch OD $\times 2.8$-inch ID $\times 2.4$-inch length). The primary difference is the bed length; therefore, flow characteristics within the unit used for testing should be nearly identical to the flight design. The effect of longer residence time for the tested unit gives more time for oxidation to occur and, therefore, produces a more conservative test condition. This is especially true for compounds such as Freon $\mathbf{2 1 8}$ that are difficult to oxidize.

\section{TEST RESULTS}

During the test, Freon 218 was injected into the process air stream upstream of the COA at 3 different rates $1.605 \mathrm{~mL} / \mathrm{s}, 2.93 \mathrm{~mL} / \mathrm{s}$, and $3.917 \mathrm{~mL} / \mathrm{s}$-to produce inlet concentrations of $154 \mathrm{mg} / \mathrm{m}^{3}$ (20 ppm), $281 \mathrm{mg} / \mathrm{m}^{3}$ (36.5 $\mathrm{ppm})$, and $375 \mathrm{mg} / \mathrm{m}^{3}$ (48.8 $\left.\mathrm{ppm}\right)$, respectively. These inlet conditions span the range of cabin concentrations observed between early September and mid-December 2001 except for the concentration peaks reported during the first Freon 218 leak. The catalyst bed temperature was maintained at approximately $384{ }^{\circ} \mathrm{C}\left(724{ }^{\circ} \mathrm{F}\right)$ throughout the test while process air flow was $4.7 \mathrm{~m}^{3} / \mathrm{h}$ $\left(2.76 \mathrm{ft}^{3} /\right.$ minute). The test flow rate is $2 \%$ higher than that normally maintained in flight. The temperature at the exit of the flight TCCS's catalyst bed is approximately $382^{\circ} \mathrm{C}\left(720^{\circ} \mathrm{F}\right)$ so the bed temperature during the test is considered appropriate.

Analysis of the air exiting the COA using detector tubes with a detection limit of $1.5 \mathrm{ppm}$ showed no HF was produced. The media in the detector tube changes from light blue to pink in the presence of HF. No color change was observed for all cases. Also, the reactor temperature remained steady before, during, and after Freon 218 injection. This observation demonstrates that there was no heat of reaction liberated in the reactor. At the highest inlet concentration, an oxidation efficiency of $1 \%$ would produce greater than $3 \mathrm{ppm}$ of HF. However, the analysis showed no HF present. Even increasing the sample volume pumped through the detector tube by a factor of 5 that would allow for $0.3 \mathrm{ppm}$ HF to be detected yielded no color change. Table 1 provides results for the 3 runs.

\section{CORRELATION TO FLIGHT OBSERVATIONS}

Flight-related observations pertaining to the potential effect that Freon 218's presence may have had on methane concentration control further support the test results. Analysis of data from Reference 4 shows the effect of halocarbons on methane oxidation in the COA to strongly correlate to the free halogen concentration in the process air stream. Figure 2 shows this correlation. The prevailing total non-Freon 218 halocarbon concentration results in a $0.72 \mathrm{mg} / \mathrm{m}^{3}$ free halogen concentration in the COA. At this level, no measurable decrease in methane oxidation efficiency is expected. Because the Freon 218 concentration reached very high levels, a significant increase in cabin methane concentration would be predicted if only $1 \%$ of the Freon 218 oxidized in the TCCS's COA.
Table 1. Test Conditions and Results

\begin{tabular}{|l|c|c|c|}
\hline \multirow{2}{*}{ PARAMETER } & \multicolumn{3}{|c|}{ TEST CONDITION } \\
\cline { 2 - 4 } & 1 & 2 & 3 \\
\hline Injection Rate & $1.605 \mathrm{~mL} / \mathrm{s}$ & $2.930 \mathrm{~mL} / \mathrm{s}$ & $3.917 \mathrm{~mL} / \mathrm{s}$ \\
Concentration & $154 \mathrm{mg} / \mathrm{m}^{3}$ & $281 \mathrm{mg} / \mathrm{m}^{3}$ & $375 \mathrm{mg} / \mathrm{m}^{3}$ \\
Start Flow Rate & $4.69 \mathrm{~m}^{3} / \mathrm{h}$ & $4.69 \mathrm{~m}^{3} / \mathrm{h}$ & $4.69 \mathrm{~m}^{3} / \mathrm{h}$ \\
Temperature 1 & $384.4^{\circ} \mathrm{C}$ & $384.2^{\circ} \mathrm{C}$ & $384.2^{\circ} \mathrm{C}$ \\
End Flow Rate & $4.69 \mathrm{~m}^{3} / \mathrm{h}$ & $4.69 \mathrm{~m}^{3} / \mathrm{h}$ & $4.67 \mathrm{~m}^{3} / \mathrm{h}$ \\
Temperature 2 & $384.3^{\circ} \mathrm{C}$ & $384.2^{\circ} \mathrm{C}$ & $384.2^{\circ} \mathrm{C}$ \\
Color Change & None & None & None \\
\hline
\end{tabular}

"Observed detector tube color change.

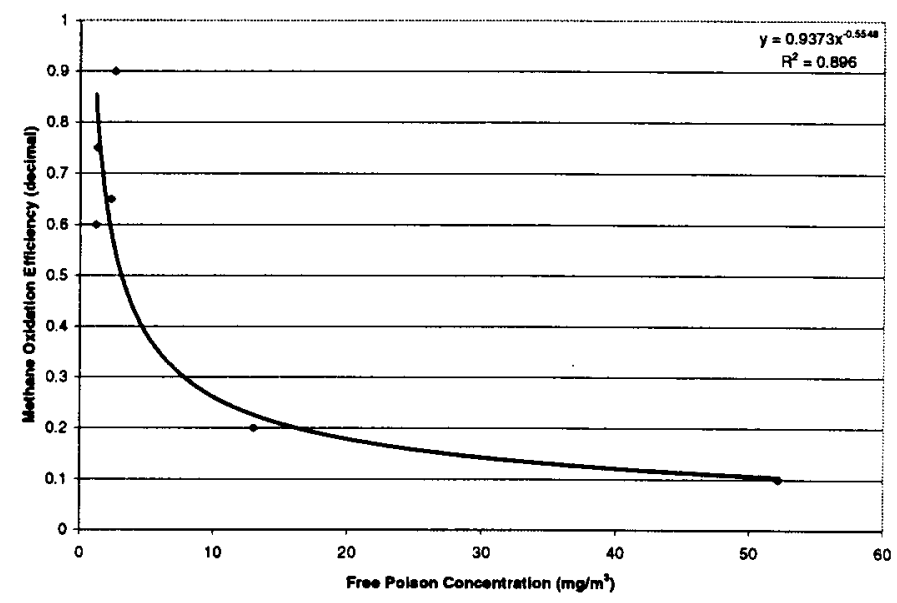

Figure 2. Effect of Free Halogen Concentration on Methane Oxidation

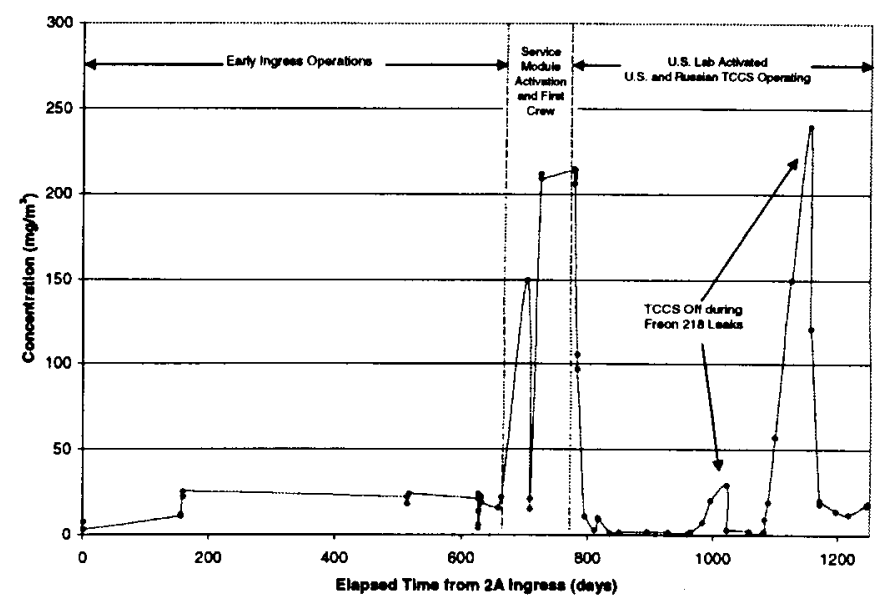

Figure 3. Methane Concentration in the ISS Cabin

Evaluation of the methane concentration profile in the ISS cabin from December 1998 through May 2002, shown by Figure 3, provides further insight into Freon 218 's effect upon methane oxidation in the COA. Residual amounts of methane were introduced into the ISS's cabin by visiting crews before the first permanent crew arrived. After that, there was no active methane removal until the TCCS was activated. During that time, the methane concentration peaked at more than $200 \mathrm{mg} / \mathrm{m}^{3}$. Once the TCCS was activated, the methane concentra- 
tion quickly fell to less than $100 \mathrm{mg} / \mathrm{m}^{3}$ and continued to less than $2 \mathrm{mg} / \mathrm{m}^{3}$. This low level was maintained throughout the ensuing station operations regardless of the concentration of Freon 218. The only instances when the methane concentration increased correspond to periods when the TCCS was shut off. The observation that there was no change in cabin methane concentration while the TCCS was operating in the presence of high Freon 218 concentrations further supports the test observation of Freon 218 oxidation in the COA.

Further evidence that Freon 218 does not react in the TCCS's COA is found by examining Figure 1. Once testing cleared the TCCS to be restarted in February 2002, its operation did not have a noticeable effect on the rate that the Freon 218 concentration decayed. Analysis, illustrated by the solid curve in Figure 1 , indicates that the removal rate is consistent with removal by the BMP alone at less than $1 \%$ efficiency for a single pass. This was consistent for the entire period between January and May 2002. Because the TCCS charcoal was saturated, this observation supports the observation that Freon 218 does not oxidize in the COA.

\section{SORBENT BED ASSEMBLY SERVICE LIFE}

\section{TESTING}

Evaluation by Lockheed between 1993 and 1995 established a service interval of 467 days (1.28 years) for the TCCS beds. $[7,8]$ This interval was based primarily upon catalyst poisoning considerations that are based upon the design specification loading of halocarbons in the cabin. In Lockheed's evaluation, halocarbons loaded the charcoal bed assembly (CBA) and then entered the COA where their oxidation poisoned the methane oxidation reaction. After 1.28 years of operation, Lockheed's assessment predicted that methane would reach its SMAC. Reaching the methane SMAC, therefore, was used to specify the bed replacement interval. Specific SBA loading was not considered in this evaluation, but SBA replacement was tied to CBA loading and replacement. Acid gas removal is described by the following net reaction equation where $\mathrm{LiOH}$ reacts with an acid gas in the presence of water vapor and carbon dioxide.

$$
\mathrm{LiOH}+\mathrm{HX} \rightarrow \mathrm{LiX}+\mathrm{H}_{2} \mathrm{O}
$$

The " $X$ " in the net equation denotes halogens such as chlorine (Cl) and fluorine (F). Essentially the reaction involves the production of an intermediate product, lithium carbonate $\left(\mathrm{Li}_{2} \mathrm{CO}_{3}\right)$, that reacts with the acid gas producing water and a nonvolatile salt.

TCCS developmental testing conducted by Lockheed and documented in 1992 showed that the measured acid gas removal performance of the SBA was $0.0194 \mathrm{~g}$ acid gas as $\mathrm{HCl} / \mathrm{g} \mathrm{LiOH}(0.0128 \mathrm{~mole} \mathrm{HCl} / \mathrm{mole} \mathrm{LiOH})$. This was much lower than the expected performance of 0.276 $\mathrm{g}$ acid gas as $\mathrm{HCl} / \mathrm{g} \mathrm{LiOH}(0.181 \mathrm{~mole} \mathrm{HCl} /$ mole $\mathrm{LiOH})$ reported by the material's vendor, Cyprus Foote Mineral
Company.[9] On a molar basis, the observed performance represents $7 \%$ of the bed's rated capacity. This equates to 3.98 moles or 95.25 grams of $\mathrm{LiOH}$ available for reaction. Lockheed proposed no explanation for the reduced capacity. However, review of the literature shows that granule size and flow distribution, temperature, contact time, and acid gas concentration entering the bed may be factors.

Evaluation of $\mathrm{Li}_{2} \mathrm{CO}_{3}$ as an acid gas control medium by Gully et al showed an experimental loading of $0.675 \mathrm{~g}$ $\mathrm{HCl} / \mathrm{g} \mathrm{Li}_{2} \mathrm{CO}_{3} .[10]$ This converts to $0.684 \mathrm{~mole} \mathrm{HCl} / \mathrm{mole}$ $\mathrm{LiOH}$ which is higher than the loading reported by Cyprus Foote Mineral Company. It is noted that the experiments conducted by Gully were carried out at $69^{\circ} \mathrm{C}\left(156^{\circ} \mathrm{F}\right)$ at a molar air flow rate of 2.9 mole $/ \mathrm{h}\left(0.065\right.$ standard $\left.\mathrm{m}^{3} / \mathrm{h}\right)$ using a $\mathrm{Li}_{2} \mathrm{CO}_{3}$ material having a $12 \times 14$ mesh granule size. The LiOH used in the TCCS's SBA is sieved to $6 \times$ 14 mesh, so slightly larger granules are packed into the SBA. This means that there is less surface area available for contact with the process air and that there may be a greater potential for flow channeling in the bed. The TCCS's process gas temperature upon exiting the COA is approximately $63^{\circ} \mathrm{C}\left(145^{\circ} \mathrm{F}\right)$. That is very close to the experimental temperature used by Gully, so any temperature effect is negligible. The contact time in the experimental bed used by Gully was approximately 0.05 seconds versus the 2.5 seconds provided by the SBA. Therefore contact time in the SBA is considered more than sufficient.

In Gully's experiments, the inlet $\mathrm{HCl}$ concentration was maintained at $45 \mathrm{ppm}$. This is substantially higher than the $<10 \mathrm{ppm}$ that entered the SBA during Lockheed's test. Most vendors acquire loading data at higher concentrations of the contaminant of interest rather than the trace levels that are experienced onboard spacecraft. This is because most industrial applications deal with much higher loadings. From this assessment, the most likely factors are the granule size which may allow flow channeling and lost performance combined with poor flow distribution at the bed inlet causing dead zones where the LiOH does not contact the flowing air stream sufficiently. Nonetheless, the performance reported by Lockheed is considered real and the SBA service life should be based upon it.

\section{DESIGN VERSUS ACTUAL HALOCARBON LOAD}

Assessment of the design specification load indicates that not all of the halocarbons will break through the charcoal bed during its 1-year service life. Using predicted concentrations from Lockheed's TCCS performance analysis, Table 2 shows that 10 out of the 25 halocarbons break through the charcoal bed within its presently-specified 1-year service life. This would produce approximately $3.46 \times 10^{-4}$ moles of acid gases as $\mathrm{HF}$ and $\mathrm{HCl} /$ hour. Table 3 lists the compounds contributing to this acid gas load. Using the LiOH utilization observed during the developmental testing, the SBA's capacity would be exhausted in approximately 480 days 
Table 2. Charcoal Loading at Design Specification Conditions

\begin{tabular}{|c|c|c|c|}
\hline COMPOUND & $\underset{\left(\mathrm{mg} / \mathrm{m}^{3}\right)}{\mathrm{C}}$ & $\begin{array}{c}M_{\text {sat }} \\
\text { (mg) }\end{array}$ & $\begin{array}{c}T_{\text {sat }} \\
\text { (days) }\end{array}$ \\
\hline Chloromethane & 0.006 & 0.05 & 0.023 \\
\hline Chloroethene & 0.0006 & 0.5 & 2.2 \\
\hline Chloroethane & 0.00002 & 0.85 & 116 \\
\hline Dichloromethane & 1.6 & 1,640 & 2.8 \\
\hline 1,1-dichloroethene & 0.0001 & 19.4 & 527 \\
\hline 1,2-dichloroethane & 0.02 & 5,445 & 741 \\
\hline Chlorobenzene & 0.31 & 227,704 & 2,000 \\
\hline 1,2-dichloropropane & 0.0015 & 8,569 & 15,557 \\
\hline Trichloromethane & 0.0036 & 809 & 612 \\
\hline Trichloroethene & 0.018 & 12,244 & 1,853 \\
\hline 1,1,1-trichloroethane & 0.14 & 44,942 & 874 \\
\hline 1,1,2-trichloroethane & 0.00002 & 642 & 87,490 \\
\hline 1,2-dichlorobenzene & 0.0013 & 153,440 & 321,434 \\
\hline Tetrachoromethane & 0.002 & 5,966 & 8,124 \\
\hline Tetrachloroethene & 0.15 & 183,891 & 3,339 \\
\hline Chlorodifluoromethane & 0.05 & 7.4 & 0.40 \\
\hline Dichlorofluoromethane & 0.00013 & 2.2 & 45.2 \\
\hline 1-chloro-1,2,2-trifluoroethane & 0.001 & 104 & 284 \\
\hline Dichlorodifluoromethane & 0.0028 & 22.5 & 22 \\
\hline Dichlorodifluoroethene & 0.00039 & 187.5 & 1,309 \\
\hline Trichlorofluoromethane & 0.29 & 6,015 & 56.5 \\
\hline Bromotrifluoromethane & 0.24 & 28 & 0.32 \\
\hline Dichlorotetrafluoroethane & 0.0054 & 3,307 & 1,668 \\
\hline Trichlorotrifluoroethane & 3.86 & 249,898 & 176 \\
\hline Tetrachlorodifluoroethane & 0.0068 & 85,640 & 34,298 \\
\hline
\end{tabular}

Table 3. Acid Gas Production at Design Specification Conditions

\begin{tabular}{|l|r|c|c|}
\hline \multicolumn{1}{|c|}{ COMPOUND } & \multicolumn{1}{c|}{$\begin{array}{c}\text { C } \\
\left(\mathbf{m g} / \mathbf{m}^{3}\right)\end{array}$} & $\begin{array}{c}\eta^{*} \\
(\%)\end{array}$ & $\begin{array}{c}\text { RATE } \\
(\text { moles/h) }\end{array}$ \\
\hline Chloromethane & 0.006 & 80 & $4.36 \times 10^{-7}$ \\
Chloroethene & 0.0006 & 80 & $3.53 \times 10^{-8}$ \\
Chloroethane & 0.00002 & 80 & $1.14 \times 10^{-9}$ \\
Dichloromethane & 1.6 & 80 & $1.38 \times 10^{-4}$ \\
Chlorodifluoromethane & 0.05 & 80 & $6.37 \times 10^{-6}$ \\
Dichlorofluoromethane & 0.00013 & 80 & $1.39 \times 10^{-8}$ \\
Dichlorodifluoromethane & 0.0028 & 70 & $2.98 \times 10^{-7}$ \\
Trichlorofluoromethane & 0.29 & 70 & $2.71 \times 10^{-5}$ \\
Bromotrifluoromethane & 0.24 & 10 & $2.96 \times 10^{-6}$ \\
Trichlorotrifluoroethane & 3.86 & 30 & $1.70 \times 10^{-4}$ \\
\hline \multicolumn{2}{|c|}{ Total Acid Gas Production (moles/h) } & $3.46 \times 10^{-4}$ \\
\hline
\end{tabular}

"COA oxidation efficiency.

(1.3 years). Saturation occurs rapidly for the halocarbons that break through the charcoal so this would imply a 480-day specification service life. As such, Lockheed's original service life recommendation of 467 days ( 1.28 years) actually allows some breakthrough of acid gases under design specification conditions.

The prevailing halocarbon loading in the ISS cabin, however, has been much lower than the design specification.
Based upon the observed loading between September 1 and December 15, 2001, there are 5 halocarbons that are predicted to have exhausted the charcoal's capacity to remove them. Table 4 shows the predicted saturation time for the observed halocarbons. Considering the degree of charcoal breakthrough that can occur for these halocarbon compounds, the compounds listed in Table 5 are the contributors to acid gas production in the COA. Using this observed loading, the acid gas production in the COA has been $9.33 \times 10^{-5}$ moles $/ \mathrm{h}$. This is $73 \%$ lower than the loading predicted by the design specification. Using the same $\mathrm{LiOH}$ utilization observed during the TCCS development testing, the SBA's projected service life is 1,778 days or 4.9 years. It should also be noted that the service life estimate is based upon actual operational time rather than calendar time. To provide some factor of safety, it is recommended that any one SBA not exceed $75 \%$ of the calculated service life. Therefore, the recommended SBA service life, based upon the prevailing halocarbon load in the ISS cabin, is 1,333 days or 3.6 years. This allows a single SBA to be used for 3 CBA service cycles with margin.

Table 4. Charcoal Loading for Observed ISS Air Quality Conditions

\begin{tabular}{|c|c|c|c|}
\hline COMPOUND & $\underset{\left(\mathrm{mg} / \mathrm{m}^{3}\right)}{\mathrm{C}}$ & $\begin{array}{l}M_{\text {sat }} \\
\text { (mg) }\end{array}$ & $\begin{array}{c}T_{\text {sat }} \\
\text { (days) }\end{array}$ \\
\hline Dichlorodifluoromethane & 0.039 & 91.3 & 9.9 \\
\hline Chloromethane & 0.041 & 0.32 & 0.021 \\
\hline Trichlorofluoromethane & 0.022 & 1,463 & 181 \\
\hline Dichloromethane & 0.937 & 1,100 & 3.2 \\
\hline Trichlorotrifluoroethane & 0.086 & 53,675 & 1,700 \\
\hline Bromotrifloromethane & 0.162 & 21.2 & 0.36 \\
\hline 1,2-dichloroethane & 0.025 & 6,175 & 673 \\
\hline Chlorobenzene & 0.025 & 78,143 & 8,512 \\
\hline
\end{tabular}

Table 5. Acid Gas Production at Observed ISS Air Quality Conditions

\begin{tabular}{|l|c|c|c|}
\hline \multicolumn{1}{|c|}{ COMPOUND } & $\begin{array}{c}\mathbf{C} \\
\left(\mathbf{m g} / \mathbf{m}^{3}\right)\end{array}$ & $\begin{array}{c}\eta^{*} \\
(\%)\end{array}$ & $\begin{array}{c}\text { RATE } \\
(\mathbf{m o l e s} / \mathbf{h})\end{array}$ \\
\hline Dichlorodifluoromethane & 0.039 & 75 & $5.22 \times 10^{-6}$ \\
Chloromethane & 0.041 & 80 & $2.98 \times 10^{-6}$ \\
Trichlorofluoromethane & 0.022 & 70 & $2.06 \times 10^{-6}$ \\
Dichloromethane & 0.937 & 80 & $8.10 \times 10^{-5}$ \\
Bromotrifluoromethane & 0.162 & 10 & $2.00 \times 10^{-6}$ \\
\hline \multicolumn{2}{|c|}{ Total Acid Gas Production (moles/h) } & $9.33 \times 10^{-5}$ \\
\hline
\end{tabular}

\section{CONCLUSIONS}

Based upon test results and engineering analysis of inflight air quality data, it is concluded that Freon 218 is not oxidized by the TCCS's COA and, therefore, does not present a risk to the TCCS's normal performance. Further evaluation of in-flight air quality data indicates that the SBA's service life is approximately 4.9 years for the prevailing non-Freon 218 halocarbon load in the cabin. 


\section{RECOMMENDATION}

According to the test results and in-flight air quality data, there is no constraint to operating the TCCS in the presence of Freon 218 and other un-branched fully fluorinated compounds. It is recommended that the SBA service life not exceed $75 \%$ of the calculated life of 4.9 years.

\section{ACKNOWLEDGMENTS}

The assessment of Freon 218 oxidation in the TCCS's COA would not have been possible without the dedicated efforts of James Tatara of Qualis Corporation who set up the injection apparatus, prepared the procedures, and ran the test. Kristin Medley, a cooperative education student from Tennessee Technological University, prepared the test plan and assisted Mr. Tatara with conducting the test.

\section{REFERENCES}

1. Wieland, P.O.: Living Together in Space-The Design and Operation of the Life Support Systems on the International Space Station. NASATMM-1998206956. NASA Marshall Space Flight Center: MSFC, Alabama; January 1998, pp. 147-155 (Volume 1), pp. 64-69 (Volume 2).

2. Perry, J.L.; Curtis, R.E.; Alexandre, K.L.; Ruggiero, L.L.; and Shtessel, N.: Performance Testing of a Trace Contaminant Control Subassembly for the International Space Station. SAE 981621. $28^{\text {th }}$ International Conference on Environmental Systems. Society of Automotive Engineers: Warrendale, PA; July 1998.

3. Curtis, R.E.; Perry, J.L.; and Abramov, L.H.: Performance Testing of a Russian Mir Space Station Trace Contaminant Control Assembly. $27^{\text {th }}$ International Conference on Environmental Systems. Society of Automotive Engineers: Warrendale, PA; July 1997.

4. Wright, J.D.; Chen, B.; and Wang, C.M.: Trace Contaminant Oxidation Catalyst Poisoning Investigation. NASA Contract NAS8-38250-15. TDA Research, Inc.: Wheat Ridge, CO; March 22, 1996, pp. 44-6.

5. Lam, C.: Toxicological Assessment of Freon 218 Leak in ISS. NASA Johnson Space Center: Houston, TX; December 14, 2000.

6. Olcott, T.; Lamparter, R.; Maine, B.; Weitzmann, A.; Luce, R.; Olivier, G.; Kawasaki, E.; Masi, O.; Richardi, C.; and Selle, J.: Design, Fabrication, and Test of a Trace Contaminant Control System. LMSCD462467. Lockheed Missiles and Space Co, Inc.; Sunnyvale, CA; November 28, 1975, pp. 160-169, 174.

7. Leban, M.I.: TCCS Performance at MTC and PMC Configurations of SSF. Engineering Memorandum TCC-0075. Lockheed Missiles and Space Co., Inc.: Sunnyvale, CA; October 29, 1993.
8. Thompson, C.E.: Scheduled Changeout Intervals for the Charcoal Bed, Sorbent Bed, Flow Meter, and Catalytic Oxidizer Assembly ORUs. Engineering Memorandum SE-0114. Lockheed Missiles and Space Co., Inc.: Sunnyvale, CA; November 22, 1995.

9. Zeppa, S.J. and Leban, M.I.: Trace Contaminant Control Subassembly Development Unit System Functional Test Report. LMSC/P024962. Lockheed Missiles and Space Co., Inc.: Sunnyvale, CA; July 29, 1992, pp. 25-27.

10. Gully, A.J.; Bethea, R.M.; Graham, R.R.; and Meador, M.C.: Removal of Acid Gases and Oxides of Nitrogen from Spacecraft Atmospheres. NASA CR-1388. Texas Technological College: Lubbock, TX, pp. 67-74.

\section{CONTACT}

Jay L. Perry is a 1985 graduate of Vanderbilt University where he earned a Bachelor of Engineering cum laude in chemical engineering. During his more than 18 years of service to the NASA, Mr. Perry has contributed significantly to the field of spacecraft environmental control and life support. His work has focused on spacecraft cabin atmosphere revitalization with a primary focus on trace contaminant control, touching nearly all facets of spacecraft contamination control for the Spacelab and Space Station programs. His work in contamination control earned Mr. Perry NASA's Exceptional Engineering Achievement Medal in 1995. Mr. Perry has authored or co-authored more than 35 NASA and conference publications in the area of spacecraft cabin air quality control and monitoring.

Jay L. Perry

National Aeronautics and Space Administration

Marshall Space Flight Center

FD21

Marshall Space Flight Center, AL 35812

Phone: 256-544-2730

Fax: 256-544-0920

Jay.L.Perry@nasa.gov 